\title{
Merkel Cell Carcinoma Clinical Regional Lymph Nodes TNM Finding v7
}

National Cancer Institute

\section{Source}

National Cancer Institute. Merkel Cell Carcinoma Clinical Regional Lymph Nodes TNM

Finding v7. NCI Thesaurus. Code C88542.

A clinical finding about one or more characteristics of Merkel cell carcinoma, following the rules of the TNM AJCC V7 classification system as they pertain to staging of regional lymph nodes. The TNM clinical and pathologic regional lymph nodes classifications of Merkel cell carcinoma are not the same. TNM clinical regional lymph nodes findings are based on clinical inspection and palpation of the regional lymph nodes and/or radiologic studies. (from AJCC 7th Ed.) 